\title{
Трансформации природных водоемов как эталон состояния водных экосистем особо охраняемых и антропогенно-нагруженных территорий
}

\author{
Г. А. Анциферова ${ }^{1 \bowtie}$, Н. И. Русова², С. Л. Шевырев ${ }^{3}$, Р. М. Нкурунзиза ${ }^{1}$, \\ О. А. Бурканова ${ }^{4}$, Л. Е. Борисова ${ }^{4}$
}

${ }^{1}$ Воронежский государственный университет, Российская Федерация

(394068, Воронеж, ул. Хользунова, 40)

${ }^{2}$ Военно-морской политехнический институт «Военно-морская академия», Российская Федерация

(196602, г. Санкт-Петербург, Кадетский бульвар 1)

${ }^{3}$ Дальневосточный геологический институт ДВО РАН, Российская Федераиия

(690022, г. Владивосток, просп. 100-летия Владивостоку, 159)

${ }^{4}$ Государственный природный заповедник «Воронинский», Российская Федераџия

(393310, Тамбовская область, п. Инжсавино, ул. Братская, 23)

\begin{abstract}
Аннотация: Цель - изучение трансформаций природных водоемов особо охраняемой территории заповедника «Воронинский» для обоснования критериев по выявлению направленности антропогенных изменений экологического состояния поверхностных вод в пределах антропогенно-нагруженных территорий на примере Воронежского водохранилища. Материаль и методы. При оценке экологического состояния водоемов использованы методы расчета индекса сапробности и сопоставления таксономического состава сообщества фитопланктона. Результаты и обсуждение. Глобальные климатические изменения проявляются в обмелении и зарастании водоемов, в увеличении объемов органического вещества, образующегося в донных осадках. Происходит формирование новых биотопов, соответственно трансформируется таксономический и экологический составы сообществ микроводорослей и цианобактерий. Влияние температурных аномалий воздуха 2010-2012 годов проявилось во вселении в озера заповедника и массовом развитии чуждых для региона теплолюбивых видов цианобактерий. «Цветение» водоемов отсутствует вследствие равновесного состояния процессов образования, накопления и минерализации органического вещества. Воронежское водохранилище является водным объектом, расположенным на антропогенно-нагруженной территории. «Цветение» вод, представлено цианобактериями рода Microcystis (Kütz.) Elenk. Температурный стресс 2010-2012 годов нашел отклик в экологическом состоянии водохранилища: «цветение» вод в 2013-2020 годах получило большее площадное распространение по акватории, и стало более продолжительным в течение вегетационного сезона, фиксируется практически с июня по октябрь. Общая тенденция формирования экологического качества вод связана с их повсеместным загрязнением, в том числе обусловленным распространением видов цианобактерий, часто в процессе метаболизма выделяющих цианотоксины. Bblвoды. Прогноз трансформации качества поверхностных вод неблагоприятен и подчеркивает остроту современной экологической ситуации.
\end{abstract}

Ключевые слова: Биоиндикация, водохранилище, поверхностные воды, озеро, микроводоросли, трансформация водных экосистем, урбанизация, фитопланктон, цианобактерии, экологическое состояние.

Источник финансирования: Исследование выполнено при финансовой поддержке РФФИ в рамках научного проекта №20-05-00779.

Для цитирования: Анциферова Г.А., Русова Н.И., Шевырев С.Л., Нкурунзиза Р. М., Бурканова О.А., Борисова Л.Е. Трансформация природных водоемов как эталон состояния водных

() Анциферова Г.А., Русова Н.И., Шевырев С. Л., Нкурунзиза Р. М., Бурканова О.А., Борисова Л.Е., 2020

\ Анциферова Галина Аркадьевна, e-mail: g_antsiferova@mail.ru

(i) Контент доступен под лицензией Creative Commons Attribution 4.0 License.

Вестник ВГУ, Серия: География. Геоэкология, 2020, № 4, 53-60 
экосистем особо охраняемых и антропогенно-нагруженных территорий // Вестник Воронежского государственного университета. Серия География. Геоэкология, 2020, №4, с. 53-60. DOI: https://doi.org/10.17308/geo.2020.4/3065

\section{ВВЕДЕНИЕ}

Актуальность исследований, связанных с изучением эколого-биологического состояния поверхностных водных объектов центральной России, в связи с их повсеместным загрязнением, трудно переоценить. Постоянная антропогенная нагрузка на поверхностные воды Европейской части России осуществляется в результате хозяйственнопромышленной и сельскохозяйственной деятельности, от транспортных и энергетических коммуникаций и других источников. В водные объекты, в том числе расположенные в пределах особо охраняемых природных территорий, загрязняющие вещества поступают повсеместно за счет рассеянного стока с водосборного бассейна и атмосферного массопереноса.

Природные водоемы изучались в заповеднике «Воронинский», расположенном в среднем течении реки Ворона в Тамбовской области, где с 2007 года нами проводился геоэкологический мониторинг состояния водоемов и водотоков. Исследование природных трансформаций водоемов заповедника, где прямая антропогенная нагрузка ограничена, проводится с целью получения критериев для выявления направленности антропогенных преобразований, проявляющихся в ухудшении экологического состояния поверхностных вод антропогенно- нагруженных и урбанизированных территорий. В качестве примера развития подобных водных экосистем рассмотрено Воронежское водохранилище.

\section{МАТЕРИАЛЫ И МЕТОДЫ}

Исследования, связанные с оценкой экологобиологического качества природных и искусственных водных объектов, опираются на методы биоиндикации по сообществам микроводорослей и цианобактерий. В основу положены расчет индекса сапробности и сопоставление таксономического состава сообщества фитопланктона и микрофитобентоса. Это позволяет представлять состояние вод числовыми значениями и проводить сопоставление результатов эколого-биологического анализа различных водоемов. Трудно переоценить значимость сопоставления таксономического состава сообщества фитопланктона. Именно данный аналитический прием позволяет определять направленность антропогенных преобразований, происходящих в водных экосистемах особо охраняемых и антропогенно-нагруженных территорий.

\section{РЕЗУЛЬТАТЫ И ИХ ОБСУЖДЕНИЕ}

\section{Водоемы государственного природного заповедника «Воронинский»}

В качестве примера природных водоемов детально изучены проточно-русловые мелководные и среднеглубокие озера Рамза и Кипец заповедника «Воронинский», которые представляют единую водную экосистему. По трофическому статусу озера относятся к эвтрофному типу.

Для функционирования сложной системы, состоящей из высшей водной растительности и сообществ микроводорослей и цианобактерий, необходима обеспеченность среды обитания биогенами. Их поставщиками являются толщи горных пород, в том числе и почвы зоны аэрации. Значительные объемы биогенных веществ поступают с водосборной площади, имеющей высокую степень сельскохозяйственного освоения.

Исследования водных экосистем особо охраняемой территории в течение 2007-2009 годов происходило в среднестатистических для региона климатических условиях. Значимость природного термического фактора для водных экосистем показали аномально высокие летние температуры воздуха и вод 2010-2012 годов. Исследования, продолженные в 2013-2019 годах, позволили проследить и оценить проявления процессов, направленных на сохранение устойчивости и стабильности озерных экосистем, их открытость потокам энергии и информации. Данные процессы нашли отражение в изменении таксономического и экологического состава сообществ фитопланктона и микрофитобентоса. Изучение космофотоснимков и непосредственные визуальные наблюдения на водоемах и прилегающих к ним водосборных поверхностях, позволили проследить динамику природных и антропогенных процессов, и проявления их воздействия на трансформацию водных экосистем $[1,6]$.

В условиях климатических изменений, связанных с температурным фактором, трансформация водных экосистем повсеместно направлена на изменение морфометрических и морфологических параметров, происходит обмеление и зарастание таких водоемов как оз. Рамза, часть акваторий оз. Кипец (залив Мохов Угол и залив Кипец). Прибрежные зоны мелеющих озер заиливаются, зара- 
стают высшей водной растительностью, частично заболачиваются. Заливы Бутыркин и Митькин Угол, входящие в состав акватории оз. Кипец, непосредственно связаны с речным потоком, останутся как мелководные и среднеглубокие водоемы. В 2007-2008 годах ниже по течению от мелеющего оз. Рамза произошло заложение нового озеровидного расширения русла реки, получившее название «Новая Заводь». Его интенсивное развитие привело к тому, что к 2017-2019 годам озерная акватория оформилась практические полностью, и как можно предположить с большой долей вероятности, в течение ближайшего десятка лет она войдет в систему оз. Рамза.

Формирующееся озеровидное расширение «Новая Заводь» положительно влияет на качество вод. Более ранние исследования показали, что в 2007-2012 годах индекс сапробности вод руслового потока, вытекающего из акватории оз. Рамза, равнялся 1,83 и 1,70 . Ниже по течению от оз. Рамза на экологическое качество вод отрицательно влияют стоки с территорий села Рамза и села Коммунарка. Негативное воздействие сохранялось до поступления водного потока в оз. Кипец, где индекс сапробности вод повышался до 2,09. Как показывают данные биоиндикации 2013-2014 и 2018-2019 годов, после прохождения потока через акваторию «Новой Заводи» экологическое качество вод улучшается за счет влияния деятельности естественных биофильтров - зарослей высшей водной растительности, о чем свидетельствует изменение значений индекса сапробности до 1,49 и 1,58 [6].

Изменение морфометрических и морфологических параметров водоемов связаны с их обмелением и зарастанием, общим увеличением органического вещества, накапливающегося в донных осадках в конце каждого сезона вегетации.

Совокупность отмеченных процессов создает широкий диапазон гидрохимических и гидрофизических условий и многообразие новых формирующихся биотопов. Соответственно происходит трансформация таксономического и экологического составов сообществ фитопланктона и микрофитобентоса, что является индикатором эколого-биологического состояния вод $[1,4]$.

В составе сообществ диатомовых водорослей с высокими оценками обилия широко представлены виды родов Fragilaria Lyngb., Synedra Ehr., Navicula Bory, Gomphonema Ehr., Epithemia Breb., Cymbella Ag., Nitzschia Hass., Cocconeis Ehr. Rhopalodia O. Müll., Amphora Ehr., Gyrosigma Hass., Cymatopleura W. Sm. и многие другие. Cpe- ди цианобактерий повсеместно с оценками обилия «нередко», «часто» и «очень часто» наблюдаются виды Microcystis pulverea (Wood) Forti emend. Elenk. et $f$. holsatica (Lemm.) Elenk., Merismopedia glauca f. insignis (Schkorb.) Geitl., Pseudoholopedia convoluta (Breb.) Elenk., Coelosphaerium kützingiana Näg., Anabaena hassalii f. minor V. Poljansk., A. spiroides Klebs, Pseudoanabaena bipes Böcher, Nodularia spumigena Mert., Spirulina abbreviata Lemm., S. Massartii (Kuff.) Geitl., Romeria leopoliensis (Racib.) Koczw., Phormidium ambiguum Gom., Ph. uncinatum (Ag.) Gom., Ph. foveolarum (Mont.) Gom., Ph. paryraceum (Ag.) Gom., Lyngbya lagerheimii (Mob.) Gom., L. aestuarii (Mert.) Liebm., L. spendens Tschern., Schizothrix fragilis (Kütz.) Gom. и многие другие.

Аномально высокие летние температуры воздуха 2010-2012 годов сопровождались повышением температуры вод. Систематическое повторение в течение трех лет высоких температур нашло отклик в составе вегетационных сукцессий фитопланктона. Это привело к снижению видового разнообразия сообществ диатомовых водорослей. Отклик сообщества цианобактерий к 2012 году проявился значительно. По сравнению с наблюдениями 2007-2009 годов увеличилось их видовое разнообразие. Получили распространение виды цианобактерий новые для водоемов региона, которые обычно фиксируются в теплых и даже горячих водах [3]. Среди них с оценками обилия «часто» - «в массе» развивались виды Phormidium tenue (Menegh.) Gom., Microcystis aeruginosa f. pseudofilomentosa (Grow) Elenk., M. ichthyoblabe Kütz., M. wesenbergii Komarek, Nematonostoc flagelliformis (Berk. et Curt.) Elenk., Spirulina meneghiniana Zanard. Начиная с 2013-2019 годов, в заливе Кипец и в оз. Рамза в обрастаниях водной растительности в сообществе цианобактерий с оценками обилия «очень часто» наблюдаются виды Mastigocladus laminosus Cohn., Anabaena contorta Bachm., A. solitaria Klebs, A. variabilis Kütz. и многие другие. В оз. Кипец с оценкой обилия «в массе» распространился вид Ostillatoria coerulescens Gicklh., характерный для условий, связанных с выделением сероводорода. На изменение экологической ситуации, обусловленной увеличением загрязнения водной среды, указывает также развитие таких таксонов, как Ostiilatoria granulata Cardner, $O$. guttalata van Goor, O. lauterbornii Schmidle, $O$. princeps Vauch., O. putrida Schmidle, O. tenius Ag., Lyngbya majuscula Harvey, Schizothrix calcicola (Ag.) Gom., часто продуцирующие цианотоксины. 
Таксономический состав сообществ цианобактерий, в том числе таксоны загрязненных местообитаний [Table. Taxonomic composition of cyanobacterial communities, including taxa of polluted habitats]

\begin{tabular}{|c|c|}
\hline $\begin{array}{c}\text { Водная экосистема особо охраняемой } \\
\text { природной территории - озера Рамза и } \\
\text { Кипец заповедника «Воронинский» / Water } \\
\text { ecosystem of a specially protected natural area - } \\
\text { Lakes Ramza and Kipets of the reserve } \\
\text { "Voroninsky" }\end{array}$ & $\begin{array}{c}\text { Водная экосистема антропогенно- } \\
\text { нагруженной территории - Воронежское } \\
\text { водохранилище / Aquatic ecosystem of } \\
\text { anthropogenically loaded and urbanized } \\
\text { territory - Voronezh reservoir }\end{array}$ \\
\hline $\begin{array}{l}\text { «Цветения» вод цианобактериями } \\
\text { не происходит / Суапоbacteria do } \\
\text { not bloom water. } \\
\text { В } 2007-2009 \text { годах широко pacпространены } \\
\text { виды Anabaena hassalii f. minor V. Poljansk., } \\
\text { A. spiroides Klebs, Borzia sudetica Erceg., } \\
\text { Coelosphaerium kützingiana Näg., Gloeocapsa } \\
\text { limnetica (Lemm.) Hollerb., Lyngbya aestuarii } \\
\text { (Mob.) Gom., L. majuscula Harvey, L. spendens } \\
\text { Tschern., Microcystis hansgirgiana (Hang.) } \\
\text { Elenk., M. pulverea (Wood) Forti emend. Elenk. } \\
\text { et f. holsatica (Lemm.) Elenk., Nodularia } \\
\text { spumigena Mert., Ostillatoria planctonica } \\
\text { Wolosz., Pseudoanabaena bipes Böcher, } \\
\text { Pseudoholopedia convoluta (Bréb.) Elenk., } \\
\text { Phormidium ambiguum Gom., Ph. foveolarum } \\
\text { (Mont.) Gom., Ph. paryraceum (Ag.) Gom., } \\
\text { Romeria leopoliensis (Racib.) Koczw., } \\
\text { Schizothrix fragilis (Kütz.) Gom., Spirulina } \\
\text { abbreviata Lemm., S. Massartii (Kuff.) Geitl., } \\
\text { S. okensis Meyer }\end{array}$ & $\begin{array}{l}\text { «Цветение» вод цианобактериями } \\
\text { постоянное / «Flowering» of waters } \\
\text { by суапоbacteria. } \\
\text { В 1988-2009 годах «цветение» вод } \\
\text { обусловлено массовым paзвитием Microcystis } \\
\text { aeruginosa Kütz. emend. Elenk. и Microcystis } \\
\text { aeruginosaf.flos-aqua (Wittr.) Elenk. }\end{array}$ \\
\hline 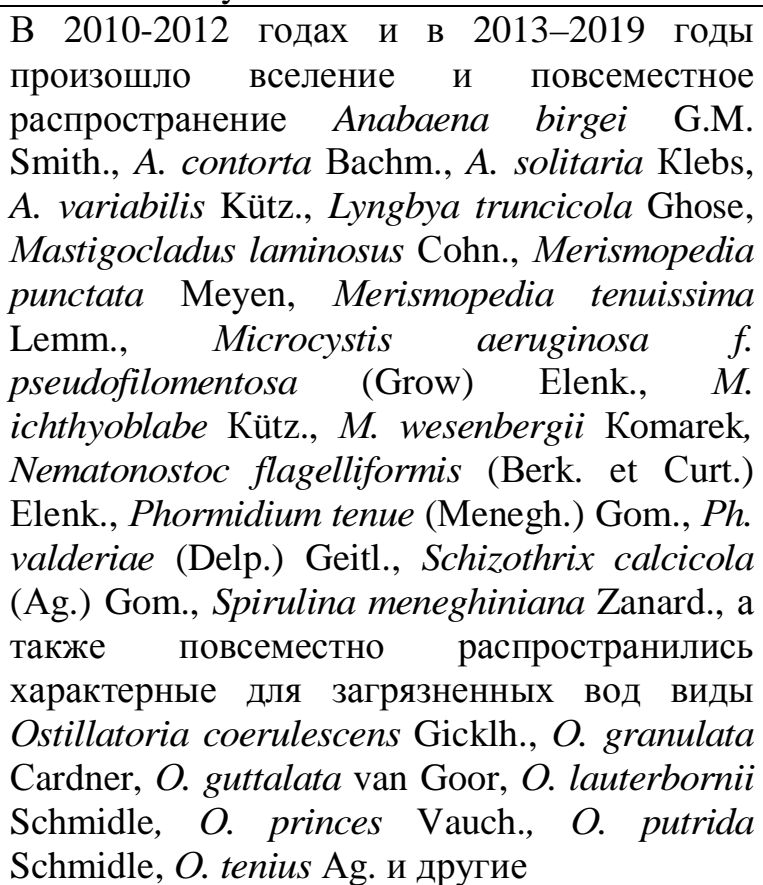 & $\begin{array}{l}\text { В 2010-2012 годах и в } 2013-2020 \text { годы } \\
\text { распространились также такие таксоны } \\
\text { «цветения» вод как Microcystis aeruginosa f. } \\
\text { pseudofilamentosa (Grow.) Elenk. et f. } \\
\text { sphaerodictyoides Elenk. et f. scripta (Richt.) } \\
\text { Elenk., M. ichthyoblabe Kütz., M. wesenbergii } \\
\text { Komarek, вид Ostillatoria coerulescens Gicklh. } \\
\text { Наряду с перечисленными, в составе видов } \\
\text { загрязненных местообитаний, в том числе } \\
\text { выделяющих цианотоксины, отмечаются } \\
\text { Anabaena flos-aquae (Lyngb.) Breb., A. } \\
\text { constricta Geitl., A. variabilis Kütz., } \\
\text { Coelosphaerium kützingianum Näg., Lyngbya } \\
\text { aestuarii (Mert.) Liebm., Merismopedia } \\
\text { tenuissima Lemm., Ostillatoria lautenbornii } \\
\text { Schmidle, O. princeps Vaucher, O. putrida Ag., } \\
\text { O. subtilissima Kütz., Phormidium foveolarum } \\
\text { (Mont.) Gom., Ph. tenue (Menegh.) Gom. и } \\
\text { другие }\end{array}$ \\
\hline
\end{tabular}


Трансформащии природных водоемов как эталон состояния водных экосистем особо охраняемых и антропогеннонагруженных территорий

Широкое распространение данных видов цианобактерий подтверждает общую тенденцию формирования повсеместного загрязнения вод.

Данные по трансформации речных водоемов заповедника «Воронинский», выразившиеся в изменении таксономического и экологического составов сообществ микроводорослей и цианобактерий в природных водоемах, позволяют применить выявленные критерии для определения состояния водных экосистем антропогенно-нагруженных территорий.

\section{Воронежское водохранилище - водоем} антропогенно-нагруженной территории

Современное состояние эколого-биологического статуса Воронежского водохранилища, расположенного среди антропогенно освоенной территории, внутри крупного областного центра, оценено по распространению сообществ микроводорослей и цианобактерий. Актуальность исследования водоема связана с тем, что он постоянно испытывает воздействие многочисленных загрязнителей - поверхностного стока с промышленных площадок и жилой застройки, транспортных коммуникаций, поступления коммунально-бытовых стоков. Анализ таксономического состава сообществ микроводорослей, и особенно цианобактерий, позволяет судить о степени загрязненности водоема и выявлять направленность происходящих в нем антропогенных преобразований $[2,5]$.

Изучение фитопланктона Воронежского водохранилища показало, что экстремальные летние температуры воздуха и вод 2010-2012 годов обострили экологическую ситуацию в водной экосистеме. Массовое развитие цианобактерий, вызвало «цветение» вод. Широко развитые зоны мелководий хорошо прогреваемого водоема являются чрезвычайно благоприятным для распространения представителей цианобактерий загрязненных местообитаний (таблица).

Сложилась достаточно опасная экологическая ситуация относительно качества водной среды. Для вегетационных сезонов 2013-2020 годов по составу водорослей - индикаторов в пределах левобережной части Нижнего приплотинного участка водохранилища воды относятся к IV классу «загрязненные» и V классу «грязные». На остальной части акватории по качеству водная среда повсеместно относится к классу III - воды «умеренно загрязненные», поскольку показатель индекса сапробности располагается в пределах значений $1,51-2,50$.

В составе сообществ цианобактерий, вызывающих «цветение» вод водохранилища, наблюда- ются виды, которые в процессе метаболизма выделяют цианотоксины. В 2013-2020 годах, массовое развитие получили виды Microcystis aeruginosa Kütz. emend. Elenk. et $f$. flos-aqua (Wittr.) Elenk. et $f$. pseudofilamentosa (Grow.) Elenk. et $f$. sphaerodictyoides Elenk. et $f$. scripta (Richt.) Elenk., M. ichthyoblabe Kütz., а также вид Ostillatoria coerulescens Gicklh. Наряду с перечисленными, в составе видов, выделяющих цианотоксины, отмечаются Anabaena constricta Geitl., A. flos-aquae (Lyngb.) Breb., A. variabilis Kütz., Coelosphaerium kützingianum Näg., Merismopedia tenuissima Lemm., Lyngbya aestuarii (Mert.) Liebm., Ostillatoria lautenbornii Schmidle., O. princeps Vaucher, $O$. putrida Ag., O. subtilissima Kütz., Phormidium tenue (Menegh.) Gom. Их распространение свидетельствует о загрязнении экосистемы и о токсичных свойствах водной среды. Причем для Воронежского водохранилища, судя по «цветению» вод, отмечающееся с 1980-х годов, характерно хроническое отравление цианотоксинами в течение многих лет. В наших работах, посвященных оценке и прогнозу эколого-санитарного состояния водохранилища, приводятся данные о содержании цианотоксинов в водах. Наибольшие значения микроцистинов фиксируются на Нижнем участке водоема, где интенсивно проявляется «цветение» вод $[2,5]$.

\section{ЗАКЛЮЧЕНИЕ}

Исследования природных водоемов заповедника «Воронинский» и искусственного водного объекта на примере Воронежского водохранилища позволили четко обозначить критерии для выявления степени загрязнения и направленности изменений экологического состояния поверхностных вод. Глобальные климатические изменения, связанные с повторением аномальных температурных условий, представляют прямую экологическую угрозу для загрязненных водоемов. Ситуация, вызванная развитием цианобактерий, которые имеют значительное биологическое воздействие на биоту и на человека, чрезвычайно неблагоприятна. При современном уровне антропогенной (техногенной) нагрузки на поверхностные воды их токсичное «цветение» цианобактериями распространено повсеместно. И подобный сценарий развития экологической ситуации достоверно прогнозируется на последующие годы.

\section{СПИСОК ЛИТЕРАТУРЫ}

1. Анциферова Г.А., Русова Н.И. Долгосрочные последствия влияния аномально высоких летних температур воздуха 2010-2012 годов на водные экосисте- 
мы лесостепной зоны // Вестник Воронежского государственного университета. Серия География. Геоэкология, 2017, № 2, с. 5-12.

2. Анциферова Г.А., Кульнев В. В., Шевырев С. Л., Беспалова Е.В., Русова Н.И., Скосарь А.Е. Искусственные водные объекты бассейна реки Воронеж и альгобиотехнология в управлении качеством вод // Экология и промышиленность России, 2018, т. 22, № 8, c. $50-54$.

3. Анциферова Г.А., Шевырев С. Л., Русова Н.И. Вселение чужеродных видов цианобактерий в водоемы средних широт в условиях высоких летних температурных аномалий воздуха // Успехи современного естествознания, 2018, № 11-2, с. 407-412.

4. Баринова С. С., Медведева Л. А., Анисимова О. В. Разнообразие водорослей-индикаторов окружающей среды. Тель-Авив, 2006. 496 с.
5. Петросян В. С., Анциферова Г.А., Акимов Л. М., Кульнев В.В., Шевырев С.Л., Акимов Е.Л. Оценка и прогноз эколого-санитарного состояния Воронежского водохранилища на 2018-2019 гг. // Экология и промышленность России, 2019, т. 23, № 7, с. 52-56.

6. Шевырев С. Л., Анциферова Г.А., Русова Н.И., Хамзикеева М.Ж. Анализ космических снимков как метод контроля природных и антропогенных процессов на примере среднего течения Вороны (Тамбовская область) // Вестник Воронежского государственного университета. Серия География. Геоэкология, 2013, № 1, c. 35-39.

Конфликт интересов: Авторы декларируют отсутствие явных и потенциальных конфликтов интересов, связанных с публикацией настоящей статьи.

Поступила в редакиию 12.08.2020

Принята к публикации 20.11.2020

\title{
Transformation of Natural Water Bodies as a Standard of the State of Water Ecosystems of Specially Protected and Urbanized Territories
}

\author{
G. A. Antsiferova ${ }^{1}$, N. I. Rusova ${ }^{2}$, S. L. Shevyrev ${ }^{3}$, R. M. Nkurunziza ${ }^{1}$, O. A. Burkanova ${ }^{4}$, \\ L. E. Borisova ${ }^{4}$ \\ ${ }^{1}$ Voronezh state university, Russia Federation \\ (1, Universitetskaya pl., Voronezh, 394018) \\ ${ }^{2}$ Naval Polytechnic Institute VUNTs of the Navy "Naval Academy", Russia Federation \\ (1, Kadetsky Boulevard, St. Petersburg, 196602) \\ ${ }^{3}$ Far Eastern Geological Institute FEB RAS, Russia Federation \\ (159, prosp. 100th anniversary of Vladivostok, Vladivostok, 690022) \\ ${ }^{4}$ State natutal reserve "Voroninsky", Russia Federation \\ (23, st. Bratskaya, Inzhavino, 393310)
}

\begin{abstract}
Purpose - Transformations of natural reservoirs of the state reserve "Voroninsky" are considered in order to obtain criteria for identifying the direction of anthropogenic changes in the ecological state of surface waters. Materials and methods. When assessing the ecological state of water bodies, methods of calculating the saprobity index and comparing the taxonomic composition of the phytoplankton community were used. Results and discussion. Global climatic changes are manifested in the shallowing and overgrowing of water bodies, in an increase in the volume of organic matter formed in bottom sediments. The formation of new biotopes is taking place, and the taxonomic and ecological composition of communities of microalgae and cyanobacteria is transformed accordingly. The influence of air temperature anomalies in 2010-2012 manifested itself in the invasion of the reserve's lakes and the mass development of thermophilic cyanobacteria species alien to the region. There is no "blooming" of water bodies due to the equilibrium state of the processes of formation, accumulation and mineralization of organic matter. The Voronezh Reservoir is a water body located in an anthropogenically loaded territory. "Bloom" of waters, represented by cyanobacteria of the
\end{abstract}

(C) Antsiferova G. A., Rusova N.I., Shevyrev S.L., Nkurunziza R.M., Burkanova O.A., Borisova L.E., 2020

$\triangle$ Galina A. Antsiferova, e-mail: g antsiferova@mail.ru

The content is available under Creative Commons Attribution 4.0 License. 
genus Microcystis (Kütz.) Elenk. The temperature stress of 2010-2012 found a response in the ecological state of the reservoir: the "bloom" of water in 2013-2020 gained a greater areal distribution over the water area, and became more prolonged during the growing season, recorded practically from June to October. The general tendency in the formation of the ecological quality of waters is associated with their widespread pollution, including those caused by the proliferation of cyanobacterial species, which often release cyanotoxins in the process of metabolism. Conclusions. The forecast of transformation of surface water quality is unfavorable and emphasizes the severity of the current ecological situation.

Key words: bioindication, water ecosystems, water storage reservoir, surface waters, lake, algal assemblages, urbanization, phytoplankton, cyanobacteria, ecological state.

Funding: The reported study was funded by RFBR, project number 20-05-00779.

For citation: Antsiferova G. A., Rusova N.I., Shevyrev S.L., Nkurunziza R.M., Burkanova O.A., Borisova L.E. Transformation of natural water bodies as a standard of the state of water ecosystems of specially protected and urbanized territories. Vestnik Voronezskogo gosudarstvennogo universiteta. Seria Geografia. Geoekologia, 2020, No. 4, pp. 53-60. (In Russ.). DOI: https://doi.org/10.17308/geo.2020.4/3065

\section{REFERENCES}

1. Antsiferova G. A., Rusova N.I. Dolgosrochnie posledstviya vliyaniya anomalno visokih letnih temperatur vozduha 2010-2012 godov na vodnie ekosistemi lesostepnoi zoni [Long-term consequences of the influence of anomalously high summer air temperatures of 2010-2012 on water ecosystems of the forest-steppe zone]. Vestnik Voronezskogo gosudarstvennogo universiteta. Seria Geografia. Geoekologia, 2017, no. 2, pp. 5-12. (In Russ.)

2. Antsiferova G. A., Kulnev V. V., Shevyrev S. L., Bespalova E. V., Rusova N. I., Skosar A. E. Iskusstvennie vodnie obekti basseina reki Voronej i algobiotehnologiya $\mathrm{v}$ upravlenii kachestvom vod [Artificial water bodies of the Voronezh river basin and algobiotechnology in water quality management]. Ekologiya i promishlennost Rossii, 2018 , v. 22 , no. 8 , pp. 50-54. (In Russ.)

3. Antsiferova G. A., Shevyrev S. L., Rusova N. I. Vselenie chujerodnih vidov cianobakterii $\mathrm{v}$ vodoemi srednih shirot $\mathrm{v}$ usloviyah visokih letnih temperaturnih anomalii vozduha [The invasion of alien species of cyanobacteria into water bodies of middle latitudes under conditions of high summer temperature anomalies of the air]. Uspehi sovremennogo estestvoznaniya, 2018, no. 11-2, pp. 407412. (In Russ.)

\section{Анциферова Галина Аркадьевна}

доктор географических наук, профессор кафедры природопользования факультета географии, геоэкологии и туризма Воронежского государственного университета, г. Воронеж, Российская Федерация, ORCID: https://orcid.org/0000-0003-0040-6564, e-mail: g_antsiferova@mail.ru

Русова Надежда Ивановна

кандидат географических наук, доцент кафедры Радиационной, химической и биологической защиты, Военно-морского политехнического института «Военно-морская академия», г. Санкт-Петербург, Российская Федерация, ORCID: https://orcid.org/0000-0002-9232-8059, e-mail:nadezhda_minnikova@mail.ru
4. Barinova S. S., Medvedeva L. A., Anisimova O. V. Rasnoobrasie vodorosley-indicatorov okrushauzhej sredi [Variety of algae indicators of the environment]. Tel-Aviv, 2006. 496 pp. (In Russ.)

5. Petrosyan V.S., Antsiferova G. A., Akimov L.M., Kulnev V. V., Shevyrev S. L., Akimov E. L. Ocenka i prognoz ekologo-sanitarnogo sostoyaniya Voronejskogo vodohranilischa na 2018-2019 gg. [Assessment and forecast of the ecological and sanitary state of the Voronezh reservoir for 2018-2019]. Ekologiya i promishlennost Rossii, 2019, v. 23 , no. 7 , pp. 52-56. (In Russ.)

6. Shevyrev S.L., Antsiferova G. A., Rusova N.I., Hamzikeeva M. J. Analiz kosmicheskih snimkov kak metod kontrolya prirodnih i antropogennih processov na primere srednego techeniya Voroni (Tambovskaya oblast) [Analysis of satellite images as a method of control of natural and anthropogenic processes (the middle flow of the Vorona River is an example)]. Vestnik Voronezskogo gosudarstvennogo universiteta. Seria Geografia. Geoekologia, 2013, no. 1, pp. 35-39. (In Russ.)

Conflict of interests: The authors declare no information of obvious and potential conflicts of interest related to the publication of this article.

Received: 12.08 .2020

Accepted: 20.11.2020

Galina A. Antsiferova

Dr. Sci. (Geogr.), Professor of the Department of nature management, Faculty of Geography, Geoecology and Tourism, Voronezh State University, Voronezh, Russia Federation, ORCID: https://orcid.org/0000-0003-0040-6564, e-mail: g antsiferova@mail.ru

Nadezhda I. Rusova

Cand. Sci. (Geogr.), Associate Professor of the Department of Radiation, Chemical and Biological Protection, Naval Polytechnic Institute VUNTs of the Navy "Naval Academy", St.-Petersburg, Russia Federation, ORCID: https://orcid.org/0000-0002-9232-8059, e-mail: nadezhda_minnikova@mail.ru 
Шевырев Сергей Леонидович

кандидат геолого-минералогических наук, научный сотрудник Дальневосточный геологический института ДВО РАН, г. Владивосток, Российская Федерация, ORCID: http://orcid.org/0000-0001-6649-7492, e-mail: shevyrev@mail.ru

Нкурунзиза Реми Мари

аспирант кафедры природопользования факультета географии, геоэкологии и туризма Воронежского государственного университета, г. Воронеж, Российская Федерация, e-mail: nremymarie@gmail.com

Бурканова Ольга Анатольевна кандидат биологических наук, директор государственного природного заповедника «Воронинский», Тамбовская область, п. Инжавино, Российская Федерация, e-mail: $\underline{\text { nauka.zap@yandex.ru }}$

Борисова Лариса Евгеньевна

старший научный сотрудник государственного природного заповедника «Воронинский», Тамбовская область, п. Инжавино, Российская Федерация, e-mail: nauka.zap@yandex.ru
Sergey L. Shevyrev

Cand. Sci. (Geol.-Miner.), Researcher of the Far East Geological Institute, FEB RAS, Vladivostok, Russia Federation, ORCID: http://orcid.org/0000-0001-6649-7492,

e-mail: shevirev@mail.ru

\section{Remy Marie Nkurunziza}

Postgraduate student of the Department of nature management, Faculty of Geography, Geoecology and Tourism, Voronezh State University, Voronezh, Russia Federation, e-mail: nremymarie@gmail.com

Olga A. Burkanova

Cand. Sci. (Biol.), Director of the state natural reserve "Voroninsky", Inzhavino, Russia Federation, e-mail: nauka.zap@yandex.ru

\section{Larisa E. Borisova}

Senior researcher of the state natural reserve "Voroninsky", Inzhavino, Russia Federation, e-mail: nauka.zap@yandex.ru 